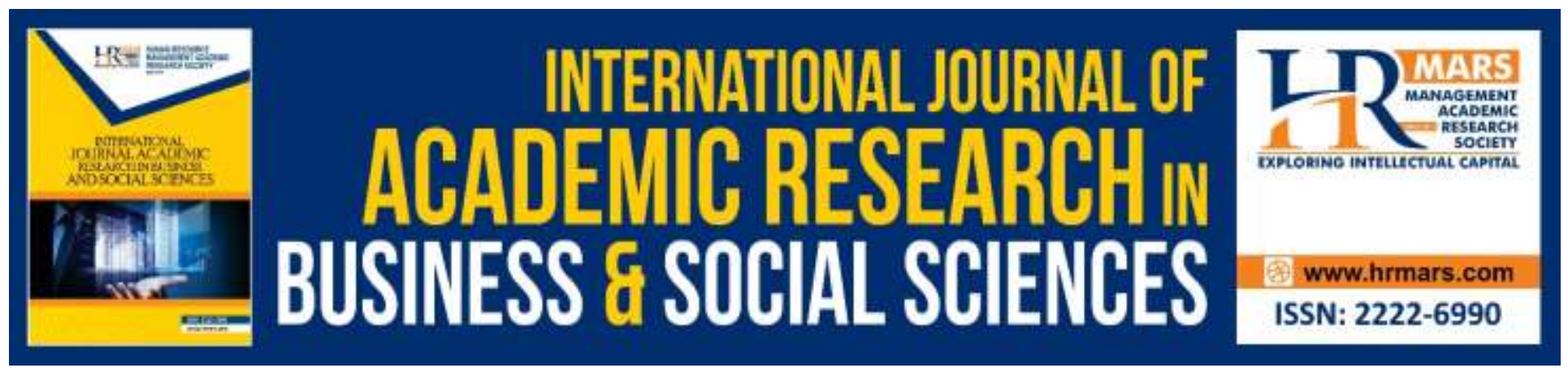

\title{
Causal Inferences - Risk-Taking Propensity Relationship Towards Entrepreneurial Intention Among Millennials
}

\author{
Noraznira Abd Razak, Najihah Hanisah Marmaya, Nur Melissa Bte \\ Mohammad Faisal Wee, Ahmad Fadhly Arham, Juan Rizal Sa'ari, Hafiza \\ Harun, Norhasliena Nordin
}

To Link this Article: http://dx.doi.org/10.6007/IJARBSS/v10-i3/7091

DOI:10.6007/IJARBSS/v10-i3/7091

Received: 08 February 2020, Revised: 25 February 2020, Accepted: 12 March 2020

Published Online: 31 March 2020

In-Text Citation: (Razak et al., 2020)

To Cite this Article: Razak, N. A., Marmaya, N. H., Wee, N. M. B. M. F., Arham, A. F., Sa'ari, J. R., \& Hafiza Harun, N. N. (2020). Causal Inferences - Risk-Taking Propensity Relationship Towards Entrepreneurial Intention Among Millennials. International Journal of Academic Research in Business and Social Sciences, 10(3), 775786.

Copyright: (C) 2020 The Author(s)

Published by Human Resource Management Academic Research Society (www.hrmars.com)

This article is published under the Creative Commons Attribution (CC BY 4.0) license. Anyone may reproduce, distribute, translate and create derivative works of this article (for both commercial and non-commercial purposes), subject to full attribution to the original publication and authors. The full terms of this license may be seen

at: http://creativecommons.org/licences/by/4.0/legalcode

Vol. 10, No. 3, 2020, Pg. 775 - 786

http://hrmars.com/index.php/pages/detail/IJARBSS

JOURNAL HOMEPAGE

Full Terms \& Conditions of access and use can be found at http://hrmars.com/index.php/pages/detail/publication-ethics 


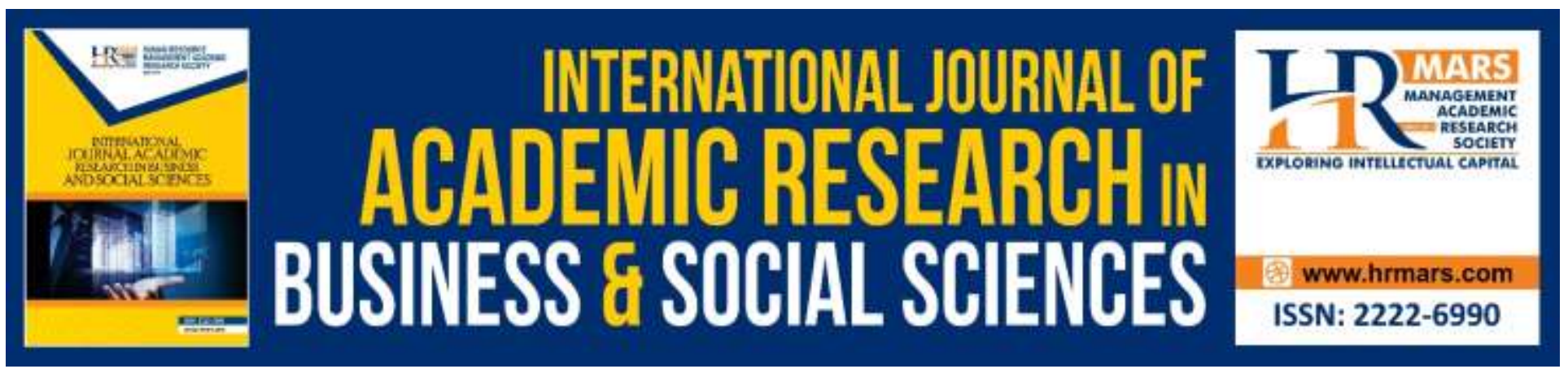

\title{
Causal Inferences - Risk-Taking Propensity Relationship Towards Entrepreneurial Intention Among Millennials
}

\author{
Noraznira Abd Razak,Najihah Hanisah Marmaya, Nur Melissa Bte \\ Mohammad Faisal Wee, Ahmad Fadhly Arham, Juan Rizal Sa'ari, \\ Hafiza Harun, Norhasliena Nordin \\ University Technology MARA Melaka, Malaysia, Export-Import Bank of Malaysia Berhad (EXIM
}

BANK)

\begin{abstract}
The study is conducted to identify the causal inferences - risk-taking propensity relationship towards entrepreneurial intention among millennials in Malacca and the relationship involves variables between attitude, perceived behavior control, subjective norm and risk-taking propensity towards entrepreneurial intention. The purpose of this research is to investigate entrepreneurial intention among millennials as part of the crucial element in our future human capital. It is important to develop youngster to become entrepreneur in order to deal with uncertainty global challenges. This study applies analysis using SPSS to a survey questionnaire of 196 respondent among millennials in Melaka, Malaysia. This study adopted Planned Behaviour Theory (TPB) as main underlying framework to further explained the variables involved.
\end{abstract}

Keywords: Risk-taking Propensity, Entrepreneurial Intention, Attitude, Subjective Norm, Perceived Behavior Control.

\section{Introduction}

The past researcher tested five factors that influence entrepreneurial intention such as need for achievement, internal locus of control, risk-taking propensity, creativity and perceived support (Phuong, 2015). The other researcher also conducted entrepreneurial intention among Saudi Arabian university students which tested three factors that influence entrepreneurial intention which are attitude towards the behavior, perceived behavioral control and subjective norm (Ali, 2016). Some researchers also tested on demographic, attitudinal factors, educational support and behavioural factors to know the entrepreneur intention (Rasli et al., 2013). There are also various study such as Sadik et. Al (2018) that emphasized the importance of social capital among millennials and how it relates towards the development of their entrepreneurial intention as well as the positive 
relationship between attitudinal astuteness and enhanced dimension of entrepreneurial skills can contribute towards networking ability among millennials (Wee, 2019). Of all the above studies mentioned, indirectly lead towards risk taking elements towards entrepreneurial intention but never been addressed clearly from the risk management perspective

Most graduates from the university preferred to work at the organization rather than being selfemployed or set up their own business. Nowadays, it is difficult to find the job and the graduate students need to compete with others in order to get the suitable job with good salary and also want a job related with their course of the study. Recent economic situation shows the not so encouraging growth indicator at $4.2 \%$ in 2016 compared to $5.0 \%$ in 2015 where some organization use retrenchment strategy to reduce their cost and employed only small number of workers (Raieh \& Sahabudin, 2016). At the same time, the advancement of technology makes the company use automation system in order to save cost.

The difficulty to find the job among millennials who are ready to forge own career path will be affected as statistic shown 1 out of 4 graduates remain unemployed 6 months after graduation, with the majority of them are degree holders. The Department of Statistic of Malaysia (DOSM) stated that total of graduates student still unemployed for 2016 is 112,000 graduates compare to year before is 108,000 (Raieh \& Sahabudin, 2016).

To solve the issue of unemployment, being an entrepreneur is one of the solutions. Graduates can choose to become entrepreneur and open up their own business. Many channel support entrepreneurial intention even at level such as 1 Pelajar 1 Perniagaan that started 1 January 2017 until 31 Disember 2026 and no fees and the students can join under this scheme (SSM, 2017). There were only small number of millennials who graduated choose to become entrepreneur even though they have knowledge and skills about entrepreneurship. It also stated by other researchers that students do not choose to become entrepreneur because of low confidents and lack encouragement from other people (Wei Ni et al., 2012). Therefore, this study is to investigate entrepreneurial intention among millennials who already undergone undergraduate studies as respondents.

\section{Literature Review}

Theory of Planned Behavior (TPB) was developed by Fishbein \& Ajzen (1975) from the Theory of Reasoned Action. In this theory, there are three kinds of factor that guide human behavior which consists of behavioral belief, normative belief and control belief. Behavioural belief produce favourable and unfavourable attitude towards the behaviour. Moreover, normative belief is come from perceived social pressure while control belief comes from perceived behavioral control. Theory Planned Behavior is thorough and reliable theoretical specification (Armitage \& Conner, 2001). Krueger et al. (2000) claimed that this theory gives significant opportunity towards better understanding and assumption of entrepreneurial action.

- Attitude

Belief and attitude shape individual behavior and thus it is very important to determine individual action (Sagiri \& Appolloni, 2009).

\section{The Relationship between Attitude and Entrepreneurial Intention}

According to Ali (2016) it was found that attitude is the most significant than other factors on entrepreneurial intention. But the other researchers stated otherwise that attitude towards income 
or money does not have significant relationship with entrepreneurial intention (Douglas \& Shepherd, 2002). Autio et al. (2001) found that attitude and entrepreneurial intention has strong relationship. Van Gelderen et al. (2008) claimed that attitude and entrepreneurial intention is significant relationship when it comes to financial security. Kadir et al. (2012) indicated that attitude has positive relationship with entrepreneurial intention as a career choice. Paco et al (2011) found that attitude towards behavior has a significant relationship with entrepreneurial intentions. Attitude is also refer to the individual ability of desire to carry out the entrepreneurial activity (Tshikovhi \& Shambare, 2015). Díaz-García et al. (2015) stated that attitude is measure commitment to set up a new business and then will lead towards entrepreneurial initiatives. Personal attitude is described as enduring personalities that include positive and negative evaluation.

\section{- Perceived Behaviour Control}

Ismail et al. (2009) stated that individual that interested elements of business environment are more willing to engage in entrepreneurship. Pihie (2009) claimed that perceived behavioural control are closely related with self-efficacy. In simple words, it is an individual belief that they are able to do the behavior. Self-efficacy is important element that direct or indirectly effect on entrepreneurial intention (Krueger et al., 2000). Chuah et al. (2016) explained in a simple word which is perceived behavioral control is perceived control or ability to carry out the behavior not based on external environment but internal belief to take a chance, face any challenges and achieve the objective. Perceived behavioural control also refer to individual ability to carry out the behaviour (Samuel et al., 2013)

\section{The Relationship between Perceived Behavioral Control and Entrepreneurial Intention}

According to Mohd Ariff et al. (2010) in their study revealed that perceived behavioral control is the strong factor that influence entrepreneurial intention. Krueger et al. (2000) also found that perceived behavior control associate with entrepreneurial intention. Autio et al. (2001) in their study revealed that perceived behavioural control is the most significant factor among Swedes into a business. The other researchers such as Paco et al. (2011) indicated that self-efficacy as known as perceived behavioral control do not have significant relationship with entrepreneurial intention. Usman (2016) found that perceived behavioural control have significant relationship with entrepreneurial intention among Muslim undergraduate students. Perceived behavioural control displayed the most significant influence on the entrepreneurial intention among new entrepreneurs creation program in Thailand (Arkarattanakul \& Lee, 2012).

\section{- Subjective Norm}

Subjective Norm is perceived social pressure whether carry out or not carry out entrepreneurial behaviour (Arkarattanakul \& Lee, 2012). In simple words, subjective norm is individual carry out the behaviour because of the pressure from family, friends, peers or society (Samuel et al., 2013). Yean et al. (2015) stated that subjective norm is individuals tend to act the recommended behavior as anticipate from their family, friends and other people. 
INTERNATIONAL JOURNAL OF ACADEMIC RESEARCH IN BUSINESS AND SOCIAL SCIENCES Vol. 10, No. 3, March, 2020, E-ISSN: 2222-6990 @ 2020 HRMARS

\section{The Relationship between Subjective Norm and Entrepreneurial Intention}

In Asia society in term of impact of social norm towards entrepreneurial intention has more significant implication than western society (Chuah et al., 2016). Social norm can weaker the individual who have strong desire or high oriented to perform the behavior (Ngoc Khuong \& Huu An, 2016). Ariff et al. (2010) stated that subjective norm have significant relationship with entrepreneurial intention.

The other researcher also supported that subjective norm have positive relationship with entrepreneurial intention (Gird \& Bagraim, 2008). Souitaris et al. (2007) in their studies found that subjective norm have significant relationship with entrepreneurial intention. (Alsos et al., 2006) found that 252 secondary school students in Nordland in Norway revealed that subjective norm affect entrepreneurial intention.

\section{- Risk-Taking Propensity}

Risk taking is happen to someone who has intention to start a business. Risk taking is related to the entrepreneurship (Gürol \& Atsan, 2006). A number of empirical research support by the other researcher stated that characteristic of entrepreneur indicate that entrepreneur prefer to take moderate risk rather than extreme risk (Mueller \& Thomas, 2000). Risk-taking propensity which is individual taking a chances in any decision the person made (Jayalakshmi \& Saranya, 2015).Student risk perception is refer to their ability to identify the opportunities and turn it into business activity even they face difficulties (Samydevan et al., 2015). Entrepreneurs who are often engage in risk taker are willing to take risk (Moree \& William, 2002). Risk propensity is the best antecedent among other entrepreneurial traits but not necessary related to the entrepreneurial performance (Hao Zhao et al., 2010).

\section{The Relationship between Risk-taking Propensity and Entrepreneurial Intention}

According to Douglas \& Shepherd (2002) stated that the more positive attitude toward risk, the stronger entrepreneurial intention. Dohse \& Walter (2010) proposed that risk-taking propensity give positively effect on entrepreneurial intention. But the other researchers oppose and they found that risk-taking propensity not significant towards entrepreneurial intention due to effect of family background (Altinay et al., 2012).

Gurel et al. (2010) and Yusof et al. (2007) stated that there is significant relationship between risktaking propensity and entrepreneurial intention. Gerry et al. (2008) indicated that risk-taking has significant relationship when it comes to the student interest and motivation to starting their own business. Wei Ni et al. (2012) stated that risk is entrepreneurial characteristic and to become an entrepreneur must have higher propensity to take risk. A few researchers found that risk taking propensity have positive relationship with entrepreneurial intention (Taramisi, 2009). Gürol \& Atsan (2006) stated that entrepreneurial students significantly high score in risk taking rather than nonentrepreneurial student.

\section{- Entrepreneurial Intention}

Intentions make someone participate in their actual behavior (Dell \& Amadu, 2015). There are many researcher studies about entrepreneurial intention and give different meaning and explanation about intention to be entrepreneur. Krueger et al. (2000) stated that individual that has intention to become 
entrepreneur will set their mind to achieve goals. The other researchers also support that statement which is persons mind can direct their attention towards specific goal and direct their effort to achieve it (Duijn, n.d.).

In addition, another researcher such as Rasli et al. (2013) indicated that individual who have initiative in entrepreneur action will have high belief of entrepreneurial which related with specific opportunity. Entrepreneurial intention is based on the willingness and skills of individual or group of individual to establish a business in the future (Radzi et al., 2013). Entrepreneurship defined as individual who start their own business and it also proved that entrepreneurship is a key to reduce poverty and promote equality for society (Tam et al., 2008).

Intention also defined as an individual cognitive that set their readiness to perform a particular behavior (Arkarattanakul \& Lee, 2012). Entrepreneurship also known as setting up a business, selfemployment and also refer to individual intention to set up a business in future (Van Gelderen et al., 2008). In simple words, intentions predict the behavior thus, it lead to specific attitude (Krueger et al., 2000). Entrepreneurial intention can be used to predict student involvement especially in entrepreneurship and also give an explanation why students are decided to venture into a business ( Ariff et al., 2010). Entrepreneur also give greater contribution by introduce good quality products, promote social, economic, political and individual well-being and social development (Ali, 2016). Zain et al. (2010) claimed that entrepreneurial intention involves standing on one's feet of their courage, goal and feeling.

Thus, four hypotheses has been established for this research namely :

H1: There is a positive relationship between attitude and entrepreneurial intention among millennials.

H2: There is a positive relationship between perceived behavior control and entrepreneurial intention among millennials.

H3: There is a positive relationship between subjective norm and entrepreneurial intention among millennials.

H4: There is a positive relationship between risk=taking propensity and entrepreneurial intention among millennials.

\section{Research Methodology}

The data was collected by using mail questionnaire. 196 selected as sample from 400 respondents which already categorize as millennials who the birth years ranging from 1981 to 1996 and already graduated at higher institution in Melaka. However, only 192 out of 196 return back the questionnaire which indicated $98 \%$ response rate. Item of the questionnaire adopted from Hisrich \& Peter (2002) and Liñán \& Chen (2009) by Cronbach Alpha of 0.55 and 0.897 respectively. Researcher used SPSS Software version 22.0, "Statistical Process for Social Science" to acquire the analysis.

\section{Results and Discussion}

Cronbach Alpha value for this study is 0.921 which is indicates as very good. The $\mathrm{R}^{2}$ percentage of variance in the independent variable stands at $71.9 \%$ that explained by the variation in the independent variables. While the rest of the $28.1 \%$ of the variance in independent variables show the result could not be explained in this study. Hence, there were other independent variables which are not included in this study that can explain the regression equation. 


\begin{tabular}{|c|c|c|c|c|}
\hline Model & $\mathrm{R}$ & R Square & Adjusted R Square & $\begin{array}{l}\text { Std. Error of the } \\
\text { Estimate }\end{array}$ \\
\hline 1 & $.848^{a}$ & .719 & .713 & .50132 \\
\hline
\end{tabular}

a. Predictors: (Constant), Attitude, Perceived Behaviour Control, Subjective Norm and Risk Taking Propensity

\section{Table $2 \mathbf{R}^{2}$ Results}

There are four hypotheses that have been summarized in Table 1 . The result shows that four independent variables are positively related with entrepreneurial intention. Multiple Regression Analysis has been used to test the hypotheses established for this study. Table 1 shows the finding of the analysis. All four of hypotheses are accepted by statistical regression.

\begin{tabular}{|l|c|c|c|}
\hline \multicolumn{1}{|c|}{ Hypothesis } & $\begin{array}{c}\text { STANDARD } \\
\text { COEFFICIENT } \\
\text { (BETA) }\end{array}$ & SIGNIFICANT & Findings \\
\hline $\begin{array}{l}\text { There is a positive relationship } \\
\text { between attitude and } \\
\text { entrepreneurial intention }\end{array}$ & .539 & .000 & Accepted \\
\hline $\begin{array}{l}\text { There is positive relationship } \\
\text { between perceived behavioral } \\
\text { control and entrepreneurial } \\
\text { intention }\end{array}$ & .135 & .005 & Accepted \\
\hline $\begin{array}{l}\text { There is positive relationship } \\
\text { between subjective norm and } \\
\text { entrepreneurial intention }\end{array}$ & .116 & .010 & Accepted \\
\hline $\begin{array}{l}\text { There is positive relationship } \\
\text { between risk-taking propensity } \\
\text { and entrepreneurial intention }\end{array}$ & .243 & .000 & Accepted \\
\hline
\end{tabular}

Table 2: Summary of Finding and Hypothesis

\section{Conclusion}

The findings stated that all variables in this research have positive relationship with entrepreneurial intention including risk- taking propensity. Independent variables such as attitude, perceived behaviour control and subjective norm already posited and proven to be positively linked with certain intention or behavior of individuals but the risk-taking attitude specially is of extra element that possibly enhanced the element of intention in a person's action and decisive manner. It warrant further research especially from risk management perspective.

\section{References}

Ajzen, I. (1991). The Theory of Planned Behavior, 5978(December 1991). 
INTERNATIONAL JOURNAL OF ACADEMIC RESEARCH IN BUSINESS AND SOCIAL SCIENCES

Vol. 10, No. 3, March, 2020, E-ISSN: 2222-6990 @ 2020 HRMARS

https://doi.org/10.1016/0749-5978(91)90020-T

Ajzen, I. (2001). Ature and. Annual Review of Psychology, 52(1), 27-58. https://doi.org/10.1146/annurev.psych.52.1.27

Ali, T. B. (2016). Explaining the Intent to Start a Business among Saudi Arabian University Students. International Review of Management and Marketing, 6(2), 345-353.

Alsos, G.A., Isaksen, E.J., \& Softing, E. (2006). Youth enterprise experience and business startup intentions. Paper Presented at the 14th Nordic Conference on Small Business Re-Search, Stockholm, (February 2014), 11-13.

Altinay, L., Madanoglu, M., Daniele, R., \& Lashley, C. (2012). The influence of family tradition and psychological traits on entrepreneurial intention. International Journal of Hospitality Management, 31(2), 489-499. https://doi.org/10.1016/j.ijhm.2011.07.007

Arkarattanakul, N., \& Lee, S. M. (2012). Determinants of Entrepreneurial Intention among Participants of The New Entrepreneurs Creation Program in Thailand. BANGKOK UNIVERSITY RESEARCH CONFERENCe, 3-22.

Armitage, C. J., \& Conner, M. (2001). Efficacy of the Theory of Planned Behaviour: a meta-analytic review. The British Journal of Social Psychology / the British Psychological Society, 40(Pt 4), 471-499. https://doi.org/10.1348/014466601164939

Autio, E., H. Keeley, R., Klofsten, M., G. C. Parker, G., \& Hay, M. (2001). Entrepreneurial Intent among Students in Scandinavia and in the USA. Enterprise and Innovation Management Studies, 2(2), 145-160. https://doi.org/10.1080/14632440110094632

Chuah, F., Ting, H., Run, E. de, \& Cheah, J. (2016). Reconsidering What Entrepreneurial Intention Implies: The Evidence from Malaysian University Students. Ijbssnet.Com, 7(9), 85-98. Retrieved from http://www.ijbssnet.com/journals/Vol_7_No_9_September_2016/10.pdf

Dahalan, N., Jaafar, M., \& Rosdi, M. S. A. (2015). Attitude and Entrepreneurial Intention Among Rural Community: the Mediating Role of Entrepreneurial Opportunity Recognition. USM-POTO International Conference on Liberal Arts and Social Sciences (ICoLASS) Location: Hanoi, VIETNAM Date: APR 25-29, 2014, 18(2010), 1005. https://doi.org/10.1051/shsconf/20151801005

Dell, E., \& Amadu, I. M. (2015). Proactive Personality and Entrepreneurial Intention: Employment Status and Student Level As Moderators. International Journal of Small Business and Entrepreneurship Research, 1(4), 1-13. https://doi.org/10.1017/CB09781107415324.004

Díaz-García, C., Sáez-Martínez, F., \& Jiménez-Moreno, J. (2015). Assessing the impact of the "Entrepreneurs" education programme on participants' entrepreneurial intentions. RUSC. Universities and Knowledge Society Journal, 12(3), 17. https://doi.org/10.7238/rusc.v12i3.2146

Dohse, D., \& Walter, S. G. (2010). The role of entrepreneurship education and regionsl context in forming entrepreneurial intentions.

Douglas, \& Shepherd. (2002). Self-employment as a Career Choice: Attitudes, Entrepreneurial Intentions, and Utility Maximization. Entrepreneurship Theory and Practice, 26(3), 81-90. https://doi.org/10.4337/9781783479801.00025

Duijn, W. (n.d.). Entrepreneurial Intention among FDEWB Students.

Fishbein, M., \& Ajzen, I. (1975). Belief, Attitude, Intention and Behaviour: An Introduction to Theory and Research. Addison-Wesley Publishing Company, (August), 480.

https://doi.org/10.2307/2065853 
INTERNATIONAL JOURNAL OF ACADEMIC RESEARCH IN BUSINESS AND SOCIAL SCIENCES Vol. 10, No. 3, March, 2020, E-ISSN: 2222-6990 ¿ 2020 HRMARS

Gird, A., \& Bagraim, J. J. (2008). The Theory of Planned Behaviour as Predictor of Entrepreneurial Intent Amongst Final-Year University Students. South African Journal of Psychology, 38(4), 711-724. https://doi.org/10.1177/008124630803800410

Gurel, E., Altinay, L., \& Daniele, R. (2010). Tourism students' entrepreneurial intentions. Annals of Tourism Research, 37(3), 646-669. https://doi.org/10.1016/j.annals.2009.12.003

Gürol, Y., \& Atsan, N. (2006). Entrepreneurial characteristics amongst university students. Education + Training, 48(1), 25-38. https://doi.org/10.1108/00400910610645716

Zhao, H., Seibert, S. E., \& Lumpkin, G. T. (2010). The Relationship of Personality to Entrepreneurial Intentions and Performance: A Meta-Analytic Review. Journal of Management, 36(2), 381-404. https://doi.org/10.1177/0149206309335187

Hisrich, R. D., \& Peters, M. P. (2002). Entrepreneurship 5th Edition (5th Editio). McGraw-Hill Higher Education.

Huda, N., Rini, N., Mardoni, Y., \& Putra, P. (2012). The Analysis of Attitudes, Subjective Norms, and Behavioral Control on Muzakki' s Intention to Pay Zakah. International Journal of Business and Social Science, 3(22), 271-279.

Ismail, M., Khalid, S. A., Othman, M., Rahman, N. A., Kassim, K. M., \& Zain, R. S. (2009).

Entrepreneurial Intention among Malaysian Undergraduates. International Journal of Business and Management, 4(10), 54-60. Retrieved from http://www.ccsenet.org/journal/index.php/ijbm/article/view/3935

Jayalakshmi, P., \& Saranya, A. S. (2015). Entrepreneurial Intention Among Students of Arts and Science Colleges in Chennai - an Empirical Study, 9(1), 6-15.

Kadir, M. B. A., Salim, M., \& Kamarudin, H. (2012). The Relationship Between Educational Support and Entrepreneurial Intentions in Malaysian Higher Learning Institution. Procedia - Social and Behavioral Sciences, 69(Iceepsy), 2164-2173. https://doi.org/10.1016/j.sbspro.2012.12.182

Keong, L. C. (2008). Entrepreneurial intention: an empirical study among Open University Malaysia students. Perspective, (January), 112.

Krueger, N. F., Reilly, M. D., \& Carsrud, A. L. (2000). Competing models of entrepreneurial intentions. Journal of Business Venturing, 15(5-6), 411-432. https://doi.org/10.1016/S08839026(98)00033-0

Kuratko, D. F. (2005). The Emergence of Entrepreneurship Education: Development, Trends, and Challenges, 577-598. https://doi.org/10.1111/j.1540-6520.2005.00099.x

McGrath, R. G., MacMillan, I. C., \& Scheinberg, S. (1992). Elitists, risk-takers, and rugged individualists? An exploratory analysis of cultural differences between entrepreneurs and nonentrepreneurs. Journal of Business Venturing, 7(2), 115-135. https://doi.org/10.1016/08839026(92)90008-F

Zani, M. R., Ahmad, S., \& Zakaria, A. (2016). The Predictors of Entrepreneurial Intention Among Undergraduate Students, 5(2), 148-158.

Sadik, M. Z. B., Wee, M., \& Rahim, F. B. A. (2018). Does Social Competency Among Entrepreneurs' Effects Their Performance? A Generation Y Perspective. Advanced Science Letters, 24(11), 8511-8513.

Michelle, L. (2016). Fresh Graduate Unemployment in Malaysia | EduAdvisor. EduAdvisor. Retrieved from https://eduadvisor.my/articles/what-didnt-know-fresh-graduate-unemploymentmalaysia-infographic/ 
INTERNATIONAL JOURNAL OF ACADEMIC RESEARCH IN BUSINESS AND SOCIAL SCIENCES Vol. 10, No. 3, March, 2020, E-ISSN: 2222-6990 @ 2020 HRMARS

Ariff, M. A. H., Bidin, Z., Sharif, Z., \& Ahmad, A. (2010). Predicting Entrepreneurship Intention Among Malay University Accounting Students in Malaysia. UNITAR E-Journal, 6(1), 1-10. Retrieved from http://search.ebscohost.com/login.aspx?direct=true \&db=a9h\&AN=51444630\&site=ehost-live

Moore, \& William. (2002). Increased information leakage from text. CEUR Workshop Proceedings, 1225(July), 41-42. https://doi.org/10.1023/A

Khuong, N. M., \& An, H. N. (2016). The Factors Affecting Entrepreneurial Intention of the Students of Vietnam National University - A Mediation Analysis of Perception toward Entrepreneurship. Journal of Economics, Business and Management, 4(2), 104-111. https://doi.org/10.7763/JOEBM.2016.V4.375

Ozaralli, N., \& Rivenburgh, N. K. (2016). Entrepreneurial intention: antecedents to entrepreneurial behavior in the U.S.A. and Turkey. Journal of Global Entrepreneurship Research, 6(1), 3. https://doi.org/10.1186/s40497-016-0047-x

Paco, A. Do., Ferreira, J., Raposo, M., Rodrigues, R. G., \& Dinis, A. (2011). Entrepreneurial intention among secondary students: findings from Portugal. International Journal of Entrepreneurship and Small Business, 13(1), 92. https://doi.org/10.1504/IJESB.2011.040418

Patrick, E. E., Richard, S., \& Robert, R. (2017). Entrepreneurial intentions of Tshwane University of Technology, Arts and Design students. African Journal of Business Management, 11(9), 175182. https://doi.org/10.5897/AJBM2017.8253

Phuong, T. H. (2015). Predictors of Entrepreneurial Intentions of Undergraduate Students in Vietnam : An Empirical Study, 5(8), 46-55. https://doi.org/10.6007/IJARBSS/v5-i8/1759

Pihie, Z. A. L. (2009). Entrepreneurship as a Career Choice : An Analysis of Entrepreneurial SelfEfficacy and Intention of University Students Entrepreneurship as a Career Choice : An Analysis of Entrepreneurial Self-Efficacy and Intention of University Students, (July).

Prianto, A. (2017). Various Variables to Trigger Entrepreneurial Intention for Young Entrepreneurs in East Java Indonesia, 6(4), 32-44.

Radzi, M., Mohd, B., Harun, R., Kheng, L. K., Anuar, A., Hanif, M., \& Gafar, B. A. (2013). Entrepreneurial Intention Among University Students ., 2013(Icebr), 1-9.

Rasli, A., Khan, S. U. R., Malekifar, S., \& Jabeen, S. (2013). Factors Affecting Entrepreneurial Intention Among Graduate Students of Universiti Teknologi Malaysia. International Journal of Business and Social Science, 4(2), 182-188.

Rauch, A., \& Frese, M. (2007). Let's put the person back into entrepreneurship research: A metaanalysis on the relationship between business owners' personality traits, business creation, and success. European Journal of Work and Organizational Psychology, 16(4), 353-385. https://doi.org/10.1080/13594320701595438

Roshlawaty Raieh, \& Marina Sahabudin. (2016). Menganggur: Mahasiswa perlu ubah mentaliti. Sinar Online. Retrieved from http://www.sinarharian.com.my/kampus/menganggurmahasiswa-perlu-ubah-mentaliti-1.553197

Ruhle, S., Muhlbauer, D., Grunhagen, M., \& Rothenstein, J. (2010). The heir of schumpeter: An insight view of students' entrepreneurial intention at the Schumpeter School of Business and Economics.

Sagiri, S., \& Appolloni, A. (2009). Identifying the Effect of Psychological Variables on Entrepreneurial Intentions. DSM Business Review, 1(2), 61-86. Retrieved from 
INTERNATIONAL JOURNAL OF ACADEMIC RESEARCH IN BUSINESS AND SOCIAL SCIENCES

Vol. 10, No. 3, March, 2020, E-ISSN: 2222-6990 @ 2020 HRMARS

http://papers.ssrn.com/sol3/papers.cfm?abstract_id=1740522

Samydevan, V., Piaralal, S., Othman, A. K., \& Osman, Z. (2015). Impact of Psychological Traits, Entrepreneurial Education and Culture in Determining Entrepreneurial Intention among PreUniversity Students in Malaysia, 5(2), 163-167.

https://doi.org/10.5923/c.economics.201501.19

Souitaris, V., Zerbinati, S., \& Al-Laham, A. (2007). Do entrepreneurship programmes raise entrepreneurial intention of science and engineering students? The effect of learning, inspiration and resources. Journal of Business Venturing, 22(4), 566-591. https://doi.org/10.1016/j.jbusvent.2006.05.002

Suruhanjaya Syarikat Malaysia (SSM). (2017). PENDAFTARAN PERNIAGAAN SECARA PERCUMA MELALUI SKIM 1PELAJAR 1PENDAFTARAN PERNIAGAAN. Retrieved May 23, 2017, from http://www.ssm.com.my/en/announcement/pendaftaran-perniagaan-secara-percumamelalui-skim-1pelajar-1pendaftaran-perniagaan

Tam, Adeline, Y. L., Chiew, Moi, T., Chang, \& Dyana, M. L. (2008). Entrepreneurial Intention of Undergraduate: The Impact of Role Model andAttitudes.

Taramisi, S.-A. (2009). An Examination on the Entrepreneurial Intention Among Thai Students at Universiti Utara Malaysia (UUM).

TERAJU. (2016). Skim Usahawan Permulaan Bumiputera (SUPERB). Retrieved May 23, 2017, from http://www.teraju.gov.my/

Thomas, A. S., \& Mueller, S. L. (2000). A case for comparative entrepreneurship: Assessing the relevance of culture. International Business Studies, 31(2), 287.

Tshikovhi, N., \& Shambare, R. (2015). Entrepreneurial knowledge, personal attitudes, and entrepreneurship intentions among South African Enactus students. Problems and Perspectives in Management, 13(1).

Usman, U. S. (2016). Factors influencing entrepreneurial intention among muslim undergraduate students.

Uygun, R., \& Kasimoglu, M. (2013). The Emergence of Entrepreneurial Intentions in Indigenous Entrepreneurs: The Role of Personal Background on the Antecedents of Intentions. International Journal of Business and Management, 8(5), 24-40. https://doi.org/10.5539/ijbm.v8n5p24

Van Gelderen, M., van Praag, C. M., \& Brand, M. (2008). Explaining Entrepreneurial Intentions By Means of the Theory of Planned Behaviour Structured Abstract Explaining Entrepreneurial Intentions By Means of the Theory of Planned Behaviour. Career Development International, 13(6), pp.538-559. https://doi.org/10.1108/13620430810901688

Wee, M., Ahmad, N. H., Sadik, M. Z., \& Abd Razak, N. (2019). Coaching millennial entrepreneurs in tourism industry: a glimpse of political skill. Journal of International Business, Economics and Entrepreneurship (JIBE), 4(2), 1-7.

Wei Ni, L., Bao Ping, L., Li Ying, L., \& Huei Wong Jia, N. (2012). Entrepreneurial Intention: a Study Among Students of Higher Learning Institution. Entrepreneurial Intention, 12(August), 181.

Y. A. Samuel., K. Ernest., J. B. A. (2013). An essessment of Entrepreneurship intention among Sunyani Polytechnic Marketing students. International Review of Management and Marketing, 3(1), 37-49.

Yean, T. F., Johari, J., \& Sukery, A. F. M. (2015). The influence of attitude, subjective norms, and 
INTERNATIONAL JOURNAL OF ACADEMIC RESEARCH IN BUSINESS AND SOCIAL SCIENCES

Vol. 10, No. 3, March, 2020, E-ISSN: 2222-6990 @ 2020 HRMARS

perceived behavioural control on intention to return to work: A case of socso???s insured employees. Kajian Malaysia, 33, 141-154.

Yusof, M., Sandhu, M. S., \& Jain, K. K. (2007). Relationship Between Psychological Characteristics and Entrepreneurial Inclination: a Case Study of Students At University Tun Abdul Razak (Unitar). Journal of Asia Entrepreneurship and Sustainability, III(2). https://doi.org/10.1108/MRR-07-2015-0169

Zain, Z. M., Akram, A. M., \& Ghani, E. K. (2010). Entrepreneurship intention among Malaysian business students. Canadian Social Science, 6(3), 34-44. https://doi.org/10.3968/g1090 